\title{
An Experimental Study of the Effect of Content Schema on English Listening Testing of Non-English Majors
}

\author{
Yue $\mathrm{Mao}^{1} \&$ Yifei Zhou ${ }^{1}$ \\ ${ }^{1}$ School of International Studies, Zhejiang University, Hangzhou, China \\ Yue Mao and Yifei Zhou contribute equally to this article \\ Correspondence: Yue Mao, School of International Studies, Zhejiang University, Hangzhou, China. E-mail: \\ my21805034@163.com
}

Received: August 2, 2020

Accepted: September 5, 2020

Online Published: September 15, 2020

doi:10.5539/ijel.v10n6p183

URL: https://doi.org/10.5539/ijel.v10n6p183

\begin{abstract}
Listening occupies one of the most preliminary parts in foreign language learning and becomes more and more important. Pre-listening process of listening comprehension owns two models, bottom-up and top-down. The latter that emphasizes the introduction of background knowledge is tightly related to content schema. The aim of the study is to examine the impact of content schema on listening comprehension and to find whether there is difference of the impact of content schema on students of different levels of listening comprehension by conducting an experiment. About 189 participants from Zhejiang University were divided into control group (CG) and experiment group (EG). Both the two groups did pretests, tests and questionnaires. CG and EG were separately divided into high- and low-level groups based on the pretest scores. Independent sample T-test was used to analyze data. The results showed that content schema negatively affected listening comprehension and it had stronger impact on students with low listening proficiency.
\end{abstract}

Keywords: content schema, listening comprehension, listening testing

\section{Introduction}

Listening, speaking, reading, writing and translating are the basic skills to learn a foreign language, among which listening is acknowledged as the most basic skill in language learning. The ultimate goal of foreign language learning is to acquire the communicative competence and listening lays the foundation for language acquisition.

The important role of listening has long been ignored under the Chinese traditional education circumstance. Listening comprehension is just regarded as the auditory input which means that teachers play recording and students finish listening tests. This situation has caused lots of problems. It is significant to make language learners listen and test listening in an effective way. This paper aims to testify the hypothesis that the content schema theory can improve the students' listening ability and help them gain better test scores when doing listening tests.

\subsection{Background of the Study}

As one of the official languages, English occupies an extremely vital role around the world, which is applied in all kinds of fields such as economy, politics, tourism and education. Under the global background, it is an undeniable trend for Chinese people to learn English. The Ministry of Education of China made English an obligatory course and designed a lot of tests to test English proficiency. But students are taught mainly on the reading and writing while listening is under-estimated, which leads to the "dumb English".

Listening is a feasible way to attain effective input and foreign language learners can master a language and acquire the communicative competence so that he or she has an integrated use of skills in speaking, reading, writing and translating. A survey shows that "people listen $45 \%$ of the time they spend in communicating and $30 \%$ of communication time was spent in speaking, 16\% reading, and 9\% writing" (Wilt, 1950).

However, there exist some problems. Most of time the traditional listening teaching method still dominates, which emphasizes the language knowledge such as new words, grammar and translation. But we should bear in mind that listening does not just mean the auditory input, which means that teacher plays recording and students 
do listening tests without introducing background knowledge and explaining the context of the prompt while students being busy listening to the materials, taking notes and answering questions. With those knowledges they learn and the background knowledge they have stored, they cannot effectively finish the listening tests. After the appearance of Schema Theory, many scholars at home and abroad have conducted researches on listening comprehension with integrated schema theory and few of them focused on the single content schema.

\subsection{Research Purposes and Significance}

The purpose of this paper is to discuss the impact of content schema on the listening ability and test scores of non-English majors. Many factors will affect listeners' listening comprehension such as the linguistic knowledge, background knowledge and the psychological states. A better grasp of linguistic knowledge can help them easily comprehend the content. A positive psychological state can raise interest and build confidence for listeners while a negative psychological state makes listeners regard it as a tough task which may directly lead to an inefficient outcome. Each language is tightly associated with its culture and history. It is not enough to only have good linguistic knowledge and positive psychological state. He must have some background knowledge stored in his mind. Johnson (1982) put forward that the second language learners can comprehend more effectively when they are familiar with the topic. The familiar topic provides background knowledge for listeners so that the text will be easier to comprehend.

Schema theory highlights the importance of background knowledge claiming that comprehension is the result of interaction between learner's background knowledge and a text in which information is connected with previously saved information in long-term memory (Cook, 1994; Widdowson, 1994). Each schema is like a knowledge framework with many slots, and when the new message and the stored background knowledge are put together at the right time, the related schema is activated so as to comprehend the new information. Within limited lime, how can foreign language learners capture all the messages delivered has been a hot issue and how to use his knowledge of the topic to listen selectively, which means they are capable of only focusing on the effective information also remains doubt. Under the background of Chinese society and culture, it is very necessary and meaningful to help foreign language learners have a better performance both on communicative listening and listening test scores.

The findings of this study will provide enough data information for the combination of schema theory with listening tests. The researchers hope to find out what impacts the content schema has on the non-English majors so that we can provide some useful instructions for the teaching of listening, motivate the highest proficiency of students when doing listening tests and make contribution to the teaching strategies applying in listening.

\subsection{Research Questions}

The study aims at answering the following questions put forward by the researches:

1) Does the content schema have significant influence (positive or negative) on students' listening test scores?

2) Are there differences on the impact of content schema on listening test scores of students with different levels?

\section{Literature Review}

\subsection{Listening Comprehension and Pre-Listening Activities}

Listening comprehension has gained more and more attention nowadays. It was stated by Rost (2002) that "since listening is the main channel of L2 acquisition, the development of listening should receive great importance in instruction". Listening comprehension was regarded as a comprehensive ability. It was closely related to the process of comprehension and speculation (Rost, 1990). Listening comprehension concerned with the abilities to memorize, to recognize and discriminate sounds, to recognize the stresses, to discern intonations, and to predict (Du, 1992). The process of listening comprehension was basically divided into three parts, namely, pre-listening, while-listening and post-listening. Pre-listening was "the stage of preparation and warming up of the whole process of listening" (Karimi, Chalak, \& Biria, 2019). Pre-listening activities can be classified into two types, namely, bottom-up and top-down. The former is always regarded as presentation of the knowledge of phonetics, vocabulary and grammar before listening, while the latter mainly concerns with presentation of background knowledge, which is closely related to schema theory that highlights the importance of it.

\subsection{Schema Theory}

"Schema theory" was first put forward by Kant (1782), which has been enriched since then. Bartlett (1932) defined schema as "the role of background knowledge in language comprehension" and "an active organization of past reactions or experience". Rumelhart (1980) further defined it as "building blocks of cognition" and "skeleton around which the situation is interpreted". Taylor and Crocker (1981) stated that the schema concerned 
with general knowledge about "some defined stimulus domain", which included "a specification of the relationships among its attributes as well as specific examples or instances of the stimulus domain". Cook (1989) declared that schema included pre-existence knowledge or background knowledge in mind. Anderson (2012) added past experiences into schema and defined it as a combination of individuals' knowledge and past experiences. Schema can be used to "process and interpret new experiences quickly and efficiently" in the process of listening comprehension (Richards \& Schmidt, 2010).

Urquhart and Weir (1998) divided different kinds of schemata into three types: "formal schemata, content schemata and cultural schemata". Subsequently, Carell (1983) added linguistic schemata to them. Yang (2010) divided schema into three types, namely, linguistic schema, formal schema and content schema. Linguistic schema consists of fundamental knowledge about phonetics, phonology, morphology, syntax. Formal schema concerns with "various background knowledge about rhetorical structure" $(\mathrm{Li}, 2018)$. Content schema relates to background knowledge and social or culture knowledge (Carrel \& Eisterhold, 1988).

\subsection{Schema Theory and Listening Comprehension}

"Schema theory" is closely related to listening comprehension, and this study focuses on content schema, or simply, background knowledge. Brown and Yule (1983) declared that when listening, listeners should employ both linguistic knowledge and non-linguistic knowledge. Huang Zidong (1998) stated that topic familiarity, proficiency level and question type affect listening comprehension for those who learn English as a foreign language. And among them topic familiarity has the most significant effect on it. Sadeghi and Zare (2002) declared that content schema was helpful for listening comprehension. Qun Li (2014) declared that equipping rich background information was helpful for English news listening. Based on a quasi-experimental design, it was found that both the two groups separately treated with schema theory approach and dynamic assessment got improved in listening comprehension, between which there was no significant difference in the posttest, in spite of the fact that schema group got higher scores (Farangi \& Kheradmand Saadi, 2017). He Xiaoyu (2016) combined lexical chunks theory with schema theory, and found that lexical chunks schema-oriented listening teaching method can effectively improve non-English majors' listening ability through an empirical study.

However, on the other hand, some researchers declared that there existed some limitations of schema theory on listening comprehension, and offering background knowledge for listeners didn't mean that listening ability can be improved. It was revealed that content schema was not helpful to improve listening comprehension performance by studying the effect of speech modification, prior knowledge and listening proficiency on listening comprehension (Chiang \& Dunkel, 1992). Jensen and Hansen (1995) stated that high proficiency listeners who have indicated prior study of a topic did not perform better on lecture comprehension than listening skills alone. The effects of prior knowledge were limited. Yang Ping and Deng Lihong (2007) found that the degree of knowing background did not necessarily have positive correlation with accuracy of listening comprehension, and even can be negative sometimes based on experiments. They also maintained that deficiency in cognitive strategies or misuse of background knowledge may bring about such a phenomenon. Same conclusion was drawn by Zhang Ting (2013) subsequently and she proposed another two factors, vocabulary and anxiety, which can affect listening comprehension besides schema theory when listening. It was believed that schema theory has some limitations and cannot be used to explain all the phenomena appearing in listening comprehension, and the misuse or overuse of schema would negatively affect listeners' understanding (Sun, 2008). Generally speaking, there exist doubts about the effect of schema on listening comprehension, which is the reason why this study is conducted.

\section{Experiment Design}

\subsection{Experiment Participants}

In this experiment, 189 undergraduates of Band 4 of English in Zhejiang University are selected, after excluding English majors who may have significantly higher level of listening comprehension and students majoring in agriculture who have abundant background knowledge of agriculture. They are from 6 English classes. This experiment is a 2 (level of listening comprehension: high and low) $\times 2$ (background knowledge: introduced and not introduced) design. For convenience's sake, 90 participants are in control group (CG) and 99 participants in experimental group (EG). However, two students in EG arrive after the start of the test, whose scores, thus, are excluded. And according to the scores of pre-tests, 30 participants are divided into high-level group of listening comprehension in CG and 60 participants the low-level group, while 37 participants is divided into high-level group of listening comprehension in EG and 60 participants the low-level group. 


\subsection{Experiment Materials and Instruments}

\subsubsection{Listening Materials}

There are four short passages in total, which are all from model tests of College English Test- 6 . The speech rate of all the four recording materials is about 150 words per minute. For all the questions, only options are presented on paper while stems can be heard in recording. Pretests include two short passages about university life, the topics of which are closed to all the participants so that the possibility could be avoided that there are significant differences on participants' background knowledge of listening content. The first passage has 292 words and 4 questions, and the second one has 284 words and 4 questions as well. Another two passages about American agriculture are used for test, among which the first had 313 words with 3 questions and the second has 286 words with 4 questions.

\subsubsection{Materials of Background Knowledge}

There were some materials of American agriculture offered as background knowledge for participants in EG, which is a general introduction about major agriculture products, farmers and employment, as well as occupational safety and health. All the information is presented by numbers, tables, and short paragraphs within 310 words, in that long passages may cause anxiety or unwillingness to read for participants.

\subsubsection{Questionnaires}

Two questionnaires are used individually to ask participants in CG and EG about their feedbacks for the test. There are two questions for CG and three for EG.

\subsection{Experiment Procedures}

All the experiment was conducted in audio-visual classroom. At first, the pretests were conducted in both CG and EG at the end of May. Teachers of these students told the students that they needed to do a listening test so that students would be willing to take the tests. The results of the tests were collected and analyzed so as to make preparations for the next step of the experiment.

Next, after making sure that there was no significant difference between the two groups, the researchers conducted the tests. In EG, at the beginning of the class, the teacher handed out the papers with the background knowledge which was relevant to the tests, told the students to carefully read the material, and have a discussion with their partners. Students were informed that these materials were related with the test they were going to do later. After 5-7 minutes, the teacher played the audio. After handing in the answer sheet, students were required to do questionnaires and then submitted their answer sheets and all the materials the teacher had given. In CG, the teacher conducted the same tests without the introduction of background knowledge and required the students to do the questionnaires. The researchers collected the data and selected the effective data, then analyzed these data. By comparing the results of the pretests, tests and questionnaires, the function of the experiment was clearly presented. The results will be discussed in detail in the following chapter.

\section{Data Analysis}

\subsection{Data Collection}

Data were collected from pre-tests, tests and questionnaires of both the two groups. For CG, 90 test papers of both pre-tests and tests were handed out and collected and the effectiveness rate of test papers was $100 \%$; for EG, 99 test papers were handed out, 2 of which were invalid as two students did not arrive on time before the experiment, and among the other 97 papers, two were outliers. Thus, the effectiveness rate of it was $96.0 \%$. As for questionnaires, 90 questionnaires in CG were handed out and collected, while 99 in EG were handed out and 97 were collected, as it was anonymous excluding the statistics of outliers is impossible. The statistics of questionnaire were quantified in the way that option $\mathrm{A}$ was equal to 4 and option $\mathrm{D}$ was equal to 1 . The data were analyzed by SPSS 25.0. Independent-Samples T test was used to analyze the data. The statistics of questionnaires were described. As the first question of both EG and CG was same, this question was analyzed by Independent-Samples $\mathrm{T}$ test

\subsection{Results and Analysis of the Pretests}

\subsubsection{Comparative Analysis of EG and CG in Pretests}

Table 1. Group statistics of EG and CG

\begin{tabular}{llllll}
\hline & group & $\mathrm{N}$ & Mean & Std. Deviation & Std. Error Mean \\
\hline pretest & CG & 90 & 3.80 & 1.637 & .173 \\
& EG & 95 & 3.89 & 1.608 & .165 \\
\hline
\end{tabular}


Table 2. Independent samples test

\begin{tabular}{|c|c|c|c|c|c|c|c|c|c|c|}
\hline & & \multicolumn{2}{|c|}{$\begin{array}{l}\text { Levene's Test for } \\
\text { Equality of } \\
\text { Variances }\end{array}$} & \multicolumn{7}{|c|}{ t-test for Equality of Means } \\
\hline & & \multirow[t]{2}{*}{$\mathrm{F}$} & \multirow[t]{2}{*}{ Sig. } & \multirow[t]{2}{*}{$\mathrm{t}$} & \multirow[t]{2}{*}{ df } & \multirow[t]{2}{*}{$\begin{array}{l}\text { Sig. } \\
\text { (2-tailed) }\end{array}$} & \multirow[t]{2}{*}{$\begin{array}{l}\text { Mean } \\
\text { Difference }\end{array}$} & \multirow[t]{2}{*}{$\begin{array}{l}\text { Std. Error } \\
\text { Difference }\end{array}$} & \multicolumn{2}{|c|}{$\begin{array}{l}95 \% \text { Confidence Interval } \\
\text { of the Difference }\end{array}$} \\
\hline & & & & & & & & & Lower & Upper \\
\hline \multirow[t]{2}{*}{ pretest } & $\begin{array}{l}\text { Equal } \\
\text { variances } \\
\text { assumed }\end{array}$ & .001 & .969 & -.397 & 183 & .692 & -.095 & .239 & -.565 & .376 \\
\hline & $\begin{array}{l}\text { Equal } \\
\text { variances not } \\
\text { assumed }\end{array}$ & & & -.397 & 182.050 & .692 & -.095 & .239 & -.566 & .376 \\
\hline
\end{tabular}

Table 1 indicates that the mean score of the $\mathrm{CG}(\mathrm{M}=3.80, \mathrm{SD}=1.637)$ is a bit lower than that of $\mathrm{EG}(\mathrm{M}=3.89$, $\mathrm{SD}=3.89$ ), which means that participants in EG perform better than participants in CG. The results of Levene's Test for Equality of Variances show that the variances are equal as the sig. value is much higher than the significance level 0.05 . The analysis of t-test reveals no significant difference between the pretests of CG and of EG, which is showed by the fact that sig. (2-tailed) value (sig. $=0.692)$ is higher than the significance level 0.05 .

It comes to the conclusion that proficiencies of students from EG and CG are similar so that the experiment can keep going and the test can be conducted.

\subsubsection{Comparative Analysis of Low-level Groups of EG and CG in Pretests}

Table 3. Group statistics of low-level groups in pretests

\begin{tabular}{llllll}
\hline & group & $\mathrm{N}$ & Mean & Std. Deviation & Std. Error Mean \\
\hline pretest & CG & 60 & 2.87 & 1.016 & .131 \\
& EG & 57 & 2.81 & .972 & .129 \\
\hline
\end{tabular}

Table 4. Independent samples test

\begin{tabular}{|c|c|c|c|c|c|c|c|c|c|c|}
\hline & & \multicolumn{2}{|c|}{$\begin{array}{l}\text { Levene's Test for } \\
\text { Equality of } \\
\text { Variances }\end{array}$} & \multicolumn{7}{|c|}{$\mathrm{t}$-test for Equality of Means } \\
\hline & & \multirow[t]{2}{*}{$\mathrm{F}$} & \multirow[t]{2}{*}{ Sig. } & \multirow[t]{2}{*}{$\mathrm{t}$} & \multirow[t]{2}{*}{$\mathrm{df}$} & \multirow[t]{2}{*}{$\begin{array}{l}\text { Sig. } \\
\text { (2-tailed) }\end{array}$} & \multirow[t]{2}{*}{$\begin{array}{l}\text { Mean } \\
\text { Difference }\end{array}$} & \multirow[t]{2}{*}{$\begin{array}{l}\text { Std. Error } \\
\text { Difference }\end{array}$} & \multicolumn{2}{|c|}{$\begin{array}{l}95 \% \text { Confidence Interval } \\
\text { of the Difference }\end{array}$} \\
\hline & & & & & & & & & Lower & Upper \\
\hline \multirow[t]{2}{*}{ pretest } & $\begin{array}{l}\text { Equal } \\
\text { variances } \\
\text { assumed }\end{array}$ & .293 & .589 & .324 & 115 & .746 & .060 & .184 & -.305 & .424 \\
\hline & $\begin{array}{l}\text { Equal } \\
\text { variances not } \\
\text { assumed }\end{array}$ & & & .325 & 114.994 & .746 & .060 & .184 & -.304 & .424 \\
\hline
\end{tabular}

It can be seen from Table 3 that the mean score of pretests of low-level group of CG is 2.87 , a little higher than that of EG $(\mathrm{M}=2.81)$. As the result in Table 4 indicated, the sig. value in Levene's Test for Equality of Variances 0.589 is higher than 0.05 , which means that the variances are equal. The value of Sig. (2-tailed) is 0.746 , higher than the 0.05 . Thus, it indicates that there is no significant difference between the pretests of low-level groups of EG and of CG, which is the basis of following analyses.

4.2.3 Comparative Analysis of High-level Groups of EG and CG in Pretest

Table 5. Group statistics of high-level groups in pretests

\begin{tabular}{llllll}
\hline & group & $\mathrm{N}$ & Mean & Std. Deviation & Std. Error Mean \\
\hline pretest & CG & 30 & 5.67 & .844 & .154 \\
& EG & 37 & 5.54 & .767 & .126 \\
\hline
\end{tabular}


Table 6. Independent samples test

\begin{tabular}{|c|c|c|c|c|c|c|c|c|c|c|}
\hline & & \multicolumn{2}{|c|}{$\begin{array}{l}\text { Levene's Test for } \\
\text { Equality of } \\
\text { Variances }\end{array}$} & \multicolumn{7}{|c|}{ t-test for Equality of Means } \\
\hline & & \multirow[t]{2}{*}{$\mathrm{F}$} & \multirow[t]{2}{*}{ Sig. } & \multirow[t]{2}{*}{$\mathrm{t}$} & \multirow[t]{2}{*}{ df } & \multirow[t]{2}{*}{$\begin{array}{l}\text { Sig. } \\
\text { (2-tailed) }\end{array}$} & \multirow[t]{2}{*}{$\begin{array}{l}\text { Mean } \\
\text { Difference }\end{array}$} & \multirow[t]{2}{*}{$\begin{array}{l}\text { Std. Error } \\
\text { Difference }\end{array}$} & \multicolumn{2}{|c|}{$\begin{array}{l}95 \% \text { Confidence Interval } \\
\text { of the Difference }\end{array}$} \\
\hline & & & & & & & & & Lower & Upper \\
\hline \multirow[t]{2}{*}{ pretest } & $\begin{array}{l}\text { Equal } \\
\text { variances } \\
\text { assumed }\end{array}$ & .003 & .959 & .640 & 65 & .525 & .126 & .197 & -.268 & .520 \\
\hline & $\begin{array}{l}\text { Equal } \\
\text { variances not } \\
\text { assumed }\end{array}$ & & & .633 & 59.391 & .529 & .126 & .199 & -.272 & .525 \\
\hline
\end{tabular}

Table 5 indicates that the variances of the high-level groups of CG and EG are equal in that the value of sig. in Levene's test is higher than 0.05 . From Tables 5 and 6 , it can been seen that the mean scores of pretests of high-level groups of CG $(M=5.67)$ is a little higher than that of EG (mean = 5.54), and the differences between the high-level groups in CG and EG is however, not statistically significant as in Table 6, the sig. (2-tailed) is lower than 0.05 .

\subsection{Results and Analysis of the Tests}

The experimental test of this study aims to find out 1) whether content schema has an impact on students' comprehensive ability and test scores; 2) whether content schema is taking effect regardless of the different levels of students. After making sure that students are at the same proficiency level through the analysis of pretests, the researches use Independent-Samples T test to analysis the tests.

\subsubsection{Comparative Analysis of EG and CG in Tests}

Table 7. Group statistics of EG and CG in tests

\begin{tabular}{llllll}
\hline & group & $\mathrm{N}$ & Mean & Std. Deviation & Std. Error Mean \\
\hline test & CG & 90 & 4.70 & 1.336 & .141 \\
& EG & 95 & 4.29 & 1.465 & .150 \\
\hline
\end{tabular}

Table 8. Independent samples test

\begin{tabular}{|c|c|c|c|c|c|c|c|c|c|c|}
\hline & & \multicolumn{2}{|c|}{$\begin{array}{l}\text { Levene's Test for } \\
\text { Equality of } \\
\text { Variances }\end{array}$} & \multicolumn{7}{|c|}{ t-test for Equality of Means } \\
\hline & & \multirow[t]{2}{*}{$\mathrm{F}$} & \multirow[t]{2}{*}{ Sig. } & \multirow[t]{2}{*}{$\mathrm{t}$} & \multirow[t]{2}{*}{ df } & \multirow[t]{2}{*}{$\begin{array}{l}\text { Sig. } \\
\text { (2-tailed) }\end{array}$} & \multirow[t]{2}{*}{$\begin{array}{l}\text { Mean } \\
\text { Difference }\end{array}$} & \multirow[t]{2}{*}{$\begin{array}{l}\text { Std. Error } \\
\text { Difference }\end{array}$} & \multicolumn{2}{|c|}{$\begin{array}{l}95 \% \text { Confidence Interval } \\
\text { of the Difference }\end{array}$} \\
\hline & & & & & & & & & Lower & Upper \\
\hline \multirow[t]{2}{*}{ test } & $\begin{array}{l}\text { Equal variances } \\
\text { assumed }\end{array}$ & .276 & .600 & 1.963 & 183 & .051 & .405 & .206 & -.002 & .813 \\
\hline & $\begin{array}{l}\text { Equal variances } \\
\text { not assumed }\end{array}$ & & & 1.967 & 182.742 & .051 & .405 & .206 & -.001 & .812 \\
\hline
\end{tabular}

Table 7 shows that the scores of participants in EG are lower than participants in CG, which is revealed by the mean scores of $\mathrm{EG}(\mathrm{M}=4.29, \mathrm{SD}=1.465)$ and of $\mathrm{CG}(\mathrm{M}=4.70, \mathrm{SD}=1.336)$, though the difference is not statistically significant. The results present a striking contrast with the results showing by Tables 1 and 2, which means, specifically, participants in EG with background knowledge who were supposed to perform better according to their better performances in pretests actually did worse than participants in CG.

\subsubsection{Comparative Analysis of Low-level Groups in EG and CG in Tests}

In order to find out whether the introduction of background knowledge has significantly different influence on different proficiency levels of students, the researches use Independent-Samples $\mathrm{T}$ test to make comparative analysis of lower-level groups and higher-level groups separately. 
Table 9. Group statistics of low-level groups in tests

\begin{tabular}{llllll}
\hline & group & N & Mean & Std. Deviation & Std. Error Mean \\
\hline test & CG & 60 & 4.27 & 1.260 & .163 \\
& EG & 57 & 4.05 & 1.540 & .204 \\
\hline
\end{tabular}

Table 10. Independent samples test

\begin{tabular}{|c|c|c|c|c|c|c|c|c|c|c|}
\hline & & \multicolumn{2}{|c|}{$\begin{array}{l}\text { Levene's Test for } \\
\text { Equality of } \\
\text { Variances }\end{array}$} & \multicolumn{7}{|c|}{ t-test for Equality of Means } \\
\hline & & \multirow[t]{2}{*}{$\mathrm{F}$} & \multirow[t]{2}{*}{ Sig. } & \multirow[t]{2}{*}{$\mathrm{t}$} & \multirow[t]{2}{*}{$\mathrm{df}$} & \multirow[t]{2}{*}{$\begin{array}{l}\text { Sig. } \\
\text { (2-tailed) }\end{array}$} & \multirow[t]{2}{*}{$\begin{array}{l}\text { Mean } \\
\text { Difference }\end{array}$} & \multirow[t]{2}{*}{$\begin{array}{l}\text { Std. Error } \\
\text { Difference }\end{array}$} & \multicolumn{2}{|c|}{$\begin{array}{l}95 \% \text { Confidence Interva } \\
\text { of the Difference }\end{array}$} \\
\hline & & & & & & & & & Lower & Upper \\
\hline \multirow[t]{2}{*}{ test } & $\begin{array}{l}\text { Equal variances } \\
\text { assumed }\end{array}$ & 2.208 & .140 & .824 & 115 & .411 & .214 & .260 & -.300 & .728 \\
\hline & $\begin{array}{l}\text { Equal variances } \\
\text { not assumed }\end{array}$ & & & .820 & 108.312 & .414 & .214 & .261 & -.303 & .731 \\
\hline
\end{tabular}

From Table 9, it can be seen that the mean of low-level group of EG in test is 4.05 and the mean of CG is 4.27 which is higher than the former by 0.22 . The result of analysis of data through Independent-Samples $T$ test is shown in Tables 5-10. According to Table 10, it reveals that the Sig. value in Levene's Test for Equality is 0.140, higher than 0.05, which means that the variances of scores of lower-level groups in EG and CG are equal. The Sig. (two-tailed) value is 0.411 , higher than 0.05 . Thus, there is no significant difference between low-level groups in EG and CG.

From the two tables, conclusion is drawn that after the application of content schema, students in EG didn't get higher scores.

4.3.3 Comparative Analysis of Scores of High-Level Groups in EG and CG in Tests.

Table 11. Group statistics

\begin{tabular}{llllll}
\hline & group & N & Mean & Std. Deviation & Std. Error Mean \\
\hline test & CG & 30 & 5.57 & 1.040 & .190 \\
& EG & 37 & 4.65 & 1.296 & .213 \\
\hline
\end{tabular}

Table 12. Independent samples test

\begin{tabular}{|c|c|c|c|c|c|c|c|c|c|c|}
\hline & & \multicolumn{2}{|c|}{$\begin{array}{l}\text { Levene's Test for } \\
\text { Equality of } \\
\text { Variances }\end{array}$} & \multicolumn{7}{|c|}{ t-test for Equality of Means } \\
\hline & & \multirow[t]{2}{*}{$\mathrm{F}$} & \multirow[t]{2}{*}{ Sig. } & \multirow[t]{2}{*}{$\mathrm{t}$} & \multirow[t]{2}{*}{$\mathrm{df}$} & \multirow[t]{2}{*}{$\begin{array}{l}\text { Sig. } \\
\text { (2-tailed) }\end{array}$} & \multirow[t]{2}{*}{$\begin{array}{l}\text { Mean } \\
\text { Difference }\end{array}$} & \multirow[t]{2}{*}{$\begin{array}{l}\text { Std. Error } \\
\text { Difference }\end{array}$} & \multicolumn{2}{|c|}{$\begin{array}{l}95 \% \text { Confidence Interva } \\
\text { of the Difference }\end{array}$} \\
\hline & & & & & & & & & Lower & Upper \\
\hline \multirow[t]{2}{*}{ test } & $\begin{array}{l}\text { Equal variances } \\
\text { assumed }\end{array}$ & .228 & .635 & 3.144 & 65 & .003 & .918 & .292 & .335 & 1.501 \\
\hline & Equal variances & & & 3.217 & 64.997 & .002 & .918 & .285 & .348 & 1.488 \\
\hline
\end{tabular}

From Table 11, it can be seen that the mean of high-level group in EG in test is 4.65 while the mean of CG is 5.57, which is higher than the former by 0.92 . The result of analysis of data through Independent-Samples $\mathrm{T}$ test is shown in Table 12. From Table 12, the Sig. value in Levene's Test for Equality is 0.635, higher than 0.05, which means that the variances of scores of higher-level groups in EG and CG are equal. The sig. (2-tailed) value is 0.003 , which do not exceed 0.05 . We can say that there exist significant differences between high-level groups of $E G$ and $C G$ in tests.

From the two tables, it comes to the conclusion that high-level students in EG get lower scores after applying the content schema. 


\subsubsection{Comparative Analysis of Scores of Low-level Students and High-Level Students in EG in Tests}

The introduction of background knowledge may exert different effects on students of different proficiency levels.

The study also wants to find out that on which levels of students the content schema will give stronger impact.

Table 13. Group statistics of scores in EG

\begin{tabular}{llllll}
\hline & group & $\mathrm{N}$ & Mean & Std. Deviation & Std. Error Mean \\
\hline test & Low-level & 57 & 4.05 & 1.540 & .204 \\
& High-level & 38 & 4.66 & 1.279 & .208 \\
\hline
\end{tabular}

Table 14. Independent samples test

\begin{tabular}{|c|c|c|c|c|c|c|c|c|c|c|}
\hline & & \multicolumn{2}{|c|}{$\begin{array}{l}\text { Levene's Test for } \\
\text { Equality of } \\
\text { Variances }\end{array}$} & \multicolumn{7}{|c|}{ t-test for Equality of Means } \\
\hline & & \multirow[t]{2}{*}{$\mathrm{F}$} & \multirow[t]{2}{*}{ Sig. } & \multirow[t]{2}{*}{$\mathrm{t}$} & \multirow[t]{2}{*}{$\mathrm{df}$} & \multirow[t]{2}{*}{$\begin{array}{l}\text { Sig. } \\
\text { (2-tailed) }\end{array}$} & \multirow[t]{2}{*}{$\begin{array}{l}\text { Mean } \\
\text { Difference }\end{array}$} & \multirow[t]{2}{*}{$\begin{array}{l}\text { Std. Error } \\
\text { Difference }\end{array}$} & \multicolumn{2}{|c|}{$\begin{array}{l}95 \% \text { Confidence Interval } \\
\text { of the Difference }\end{array}$} \\
\hline & & & & & & & & & Lower & Upper \\
\hline \multirow[t]{2}{*}{ test } & $\begin{array}{l}\text { Equal variances } \\
\text { assumed }\end{array}$ & 2.710 & .103 & -2.004 & 93 & .048 & -.605 & .302 & -1.205 & -.006 \\
\hline & $\begin{array}{l}\text { Equal variances } \\
\text { not assumed }\end{array}$ & & & -2.080 & 88.473 & .040 & -.605 & .291 & -1.184 & -.027 \\
\hline
\end{tabular}

In the pretests of EG, the mean of low-level group is 2.81 while the mean of high-level group is 5.53 , which exceeds the former by 2.72 . From Table 13, the mean of low-level group in test is 4.05 while the mean of high-level group is 4.66 , which exceeds the former by 0.61 . From Table 14, the sig. (2-tailed) value is 0.048 , which does not exceed 0.05 . We can say that there exists significant difference between high-level groups and low-level groups in EG in test.

However, though there still exists significant difference between the two groups, it shows that the scores of lower-levels students are improved to a higher degree. The application of content schema exerts stronger impact on lower levels students compared with the high-level students in EG.

\subsection{Results and Analysis of Questionnaires}

Participants in CG were asked two questions. Those are how easy the listening comprehension task was $(1=$ very difficult, 4 = very easy), and to what extent they believe that they need background knowledge to be offered before listening $(1=$ very much so, $4=$ not at all $)$. The results of the questionnaires are shown in Table 15 .

Table 15. Descriptive statistics of CG

\begin{tabular}{lllllll}
\hline & $\mathrm{N}$ & Minimum & Maximum & Mean & Std. Deviation & Variance \\
\hline $\mathrm{q} 1$ & 83 & 1 & 4 & 2.48 & .802 & .643 \\
$\mathrm{q} 2$ & 83 & 1 & 4 & 2.64 & .805 & .648 \\
Valid N (listwise) & 83 & & & & & \\
\hline
\end{tabular}

Participants in EG were asked three questions, namely, how easy the listening comprehension task was $(1=$ very difficult, 4 = very easy), how helpful the background knowledge offered to them was $(1=$ very helpful, $4=$ not helpful at all $)$ and to what extent they think that the background knowledge disturbs them when listening $(1=$ very much, $4=$ not at all). The results are shown in Table 16 :

Table 16. Descriptive statistics of EG

\begin{tabular}{lllllll}
\hline & N & Minimum & Maximum & Mean & Std. Deviation & Variance \\
\hline q1 & 97 & 1 & 4 & 2.37 & .795 & .632 \\
q2 & 97 & 1 & 4 & 2.48 & .779 & .607 \\
q3 & 97 & 1 & 4 & 2.67 & .774 & .598 \\
Valid N (listwise) & 97 & & & & & \\
\hline
\end{tabular}


As the first questions are same in both CG and EG, the results of them were compared by Independent-Samples

$\mathrm{T}$ test, which are shown in Table 17.

Table 17. Independent samples test

\begin{tabular}{|c|c|c|c|c|c|c|c|c|c|c|}
\hline & & \multicolumn{2}{|c|}{$\begin{array}{l}\text { Levene's Test for } \\
\text { Equality of } \\
\text { Variances }\end{array}$} & \multicolumn{7}{|c|}{ t-test for Equality of Means } \\
\hline & & \multirow[t]{2}{*}{$\mathrm{F}$} & \multirow[t]{2}{*}{ Sig. } & \multirow[t]{2}{*}{$\mathrm{t}$} & \multirow[t]{2}{*}{$\mathrm{df}$} & \multirow[t]{2}{*}{$\begin{array}{l}\text { Sig. } \\
\text { (2-tailed) }\end{array}$} & \multirow[t]{2}{*}{$\begin{array}{l}\text { Mean } \\
\text { Difference }\end{array}$} & \multirow[t]{2}{*}{$\begin{array}{l}\text { Std. Error } \\
\text { Difference }\end{array}$} & \multicolumn{2}{|c|}{$\begin{array}{l}95 \% \text { Confidence Interval } \\
\text { of the Difference }\end{array}$} \\
\hline & & & & & & & & & Lower & Upper \\
\hline \multirow[t]{2}{*}{ q1 } & $\begin{array}{l}\text { Equal variances } \\
\text { assumed }\end{array}$ & .033 & .856 & .928 & 178 & .354 & .111 & .119 & -.125 & .346 \\
\hline & $\begin{array}{l}\text { Equal variances } \\
\text { not assumed }\end{array}$ & & & .928 & 173.240 & .355 & .111 & .119 & -.125 & .346 \\
\hline
\end{tabular}

From the three tables, participants in EG reported greater difficulty in their task $(\mathrm{M}=2.37, \mathrm{SD}=0.795)$ compared with those in $\mathrm{CG}(\mathrm{M}=2.48, \mathrm{SD}=0.802)$, while the difference is not statistically significant $($ Sig. $(2$-tailed $)=0.354)$ with the basis that variances are equal. For participants in CG, the extent to which they believe that they need background knowledge is moderate $(\mathrm{M}=2.64, \mathrm{SD}=0.805)$. For those in $\mathrm{EG}$, the extent to which they think background knowledge is helpful $(\mathrm{M}=2.48, \mathrm{SD}=0.779)$ is a little higher than the extent to which they think background knowledge disturbs them $(\mathrm{M}=2.67, \mathrm{SD}=0.774)$.

\subsection{Discussion}

Through the data analyses on listening pretests, tests and questionnaires, it is obvious that the situation does not going on as expected.

In the pretests, the means of the two groups and the Sig. value in Independent-Samples T test show that there is no significant difference between the two groups, under which circumstance the tests and questionnaires can be conducted.

In the analysis of tests, however, the score of EG don't improve and indeed it decreases. In general, comparing the test scores of EG and CG, it draws the surprising conclusion that students who are applied with the content schema don't perform better than those still taught under the traditional mode. The two groups don't have significant difference. Then the researches try to analyze more specifically. In the comparison between low-level groups of EG and CG, the mean score of EG is lower than the CG, though there is no significant difference between the two groups, it still shows that students of lower listening proficiency in EG did worse than those in CG. In the comparison of high-level group of EG and CG, the mean score of EG is clearly lower than the mean score of CG. Based on the Independent-Samples T test, there is significant difference between the two groups, which reveals that after the application of content schema, students with higher listening proficiency in EG perform worse than those in CG. There may be several factors that will lead to the situation such as the interference of the background knowledge, students' inertial thinking, memory feud and so on.

To testify the second hypothesis (does content schema have different influence on students with different listening proficiencies?), the Independent-Samples $T$ test is also conducted between the high-level group and low-level group of EG. Looking at the Sig. value, there is significant difference between the two groups. But the mean score of low-level group has been improved a lot and is close to the high-level group. It shows that the introduction of background knowledge has strongly positive impact on low-level students.

Through the questionnaires, it shows that almost all the students in EG and CG hardly have acknowledged the function of content schema. They hold the view that the help of background knowledge for them doesn't matters. It is not of great help. Some students regard it as interruptive, but through the data analysis, the extent to which they think background knowledge is helpful is a little higher than the extent to which they think background knowledge disturb them.

All these changes above prove that the results of the experiment do not testify the first hypothesis. The application of schema theory doesn't improve students' listening performance and even make the students perform worse than those without the introduction of background knowledge. The experiment also shows that the content schema has stronger impact on students with lower level than students with higher level though the impact is not significant. 


\section{Conclusion}

Listening occupies one of the most elementary parts in the learning of foreign language. In China, English listening has been falsefully treated and has long been the headache for many students, which is due to the wrong mode that listening is a passive activity as teacher playing recording and students listening the radio. This article aims to testify the impact of content schema on non-English majors from theory and experiment in order to enhance students' listening ability. Listeners' background knowledge largely influences students listening behavior. Whether applying content schema can lead listeners to retrieve or construct information from their own previously acquired knowledge and experiences remains controversial. This study conducts experiment to provide data analysis for finding out the actual impact of content schema.

In this chapter, the researches talk about some major findings, and limitations of the study and hope to provide some suggestions for further research.

\subsection{Major Findings}

The experiment of this study is conducted based on the research questions whether listeners who have been introduced the background knowledge will perform better than those who do not receive the introduction of background knowledge and whether students of different English proficiency levels who receive the background knowledge will perform differently. The collected data have proved that the answer for the first is no.

First, students' listening abilities don't seem to have been improved. Students in EG seem to perform worse than those in CG. It can be seen that the mean scores of EG and CG in the pretests are nearly equal, while after applying the content schema, the mean scores of EG decrease by 0.41 and the Sig. value which is 0.051 shows no significant difference between EG and CG. When analyzing different levels of students in EG and CG, there is significant difference between high-level students and the mean score of high-level students in EG is lower than that of CG. Therefore, the high listening proficiency students of EG are interfered by the background knowledge which may be explained by their change of listening habits, inertial thinking, and memory feud. When it comes to the impact of content schema on students of different levels, the data show that low-level students' scores have been increased to a large extent. Maybe students of low-level lack enough knowledge in their mind and their foundations are weak in that introduction of background knowledge can reduce their anxiety when doing English test so that the introduction can help them gain some effective messages and calm them down. Therefore, their performances in test have been improved.

The analysis of questionnaires reveals that students' attitudes towards the application of content schema also present a striking result. Most of students think that the introduction of background knowledge doesn't matter a lot, while the extent to which they think background knowledge is helpful is just a little higher than the extent to which they think background knowledge disturb them.

In conclusion, the study found that the application of content schema does not improve the listening ability and to some extent will disturb the performance of students. But it will exert more positive impact on students with lower listening proficiency in experiment group than those with higher listening proficiency though the change is not significantly different.

\subsection{Limitations}

Though the experiment proves the un-effectiveness of content schema in listening comprehension and listening test, there is no doubt that there exist some limitations due to the limited research conditions and short-term implement.

First, the participants attending this experiment are non-English majors of Band 4 in Zhejiang University. The participants are not of diversity. Whether there is a wide range of possibilities for this experiment still remains to be testified.

Second, the experiment time is short. Within limited time, the experiment can't completely and accurately reflect the real effect of content schema theory in listening comprehension. The experiment may have different results if it lasts for a longer period. Therefore, further research can expand the experiment time.

Last, the reliability and validity of the questionnaires should be enhanced because these questions are based on the researchers' understanding. The questions of the questionnaires can be more objective and professional in later research after consulting some teaching experts.

\subsection{Implications}

As far as the results of the study are concerned, there are some implications of listening teaching. 
First, offering background knowledge before listening is not always benefit for listening comprehension. Specifically, if the impacts exist, it is more obvious for students with low-level listening ability.

Secondly, it should be cautious to provide background knowledge as it can be affected by listening habits, cognitive ability or cognitive strategies as well. Memory feud may happen to listeners, or some cognitive strategies such as inertial thinking may negatively affect listening comprehension when background knowledge is provided. Thus, mere content schema is not sufficient to improve listening ability, which also requires listeners' positive cognitive strategies and listening habits. As a result, teachers are supposed to attach importance to teach cognitive strategies and alter students' bad listening habits.

\section{References}

Anderson, J. R. (2012). Cognitive psychology and its enlightenment (7th ed.). Beijing: People's Posts and Telecommunications Press.

Bartlett, F. C. (1932). Remembering. Cambridge: Cambridge University Press.

Brown, G., \& Yule, G. (1983). Discourse analysis. Cambridge: Cambridge University Press. https://doi.org/10.1017/CBO9780511805226

Carrell, P. L. (1983). Some issues in Studying the role of schemata, or background knowledge in second language comprehension. Reading in a Foreign Language, 1, 81-92.

Carrell, P. L., \& Eisterhold, J. C. (1983). Schema theory and ESL reading pedagogy. Tesol Quarterly, 17(4), 553-573. https://doi.org/10.1017/CBO9781139524513.010

Chiang, C. S., \& Dunkel, P. (1992). The effect of speech modification, prior knowledge, and listening proficiency on EFL lecture learning. TESOL Quarterly, 26(2), 345-374. https://doi.org/10.2307/3587009

Cook, G. (1989). Discourse. Oxford: Oxford University Press.

$\mathrm{Du}$, J. (1992). Listening comprehension process and listening assessment methods. Foreign Language Teaching and Research, 4, 47-51.

Farangi, M. R., Kheradmand, S. Z., \& Gritter, K. (2017). Dynamic assessment or schema theory: the case of listening comprehension. Cogent Education, 4(1). https://doi.org/10.1080/2331186X.2017.1312078

He, X. (2016). Non-English majors' listening teaching based on lexical chunks theory and schema theory. English Language Teaching, 9(2), 142. https://doi.org/10.5539/elt.v9n2p142

Huang, Z. D. (1998). The Effects of Topic Familiarity, Proficiency Level and Question Type on EFL Listening Comprehension: ST and RT Perspectives. Modern Foreign Languages, 4, 22-45.

Jensen, C., \& Hansen, C. (1995). The effect of prior knowledge on EAP listening-test performance. Language Testing, 12(1), 99-119. https://doi.org/10.1177/026553229501200106

Johnson, P. (1982). Effects on Reading Comprehension of Building Background Knowledge. Tesol Quarterly, 16(4), 503-516. https://doi.org/10.2307/3586468

Karimi, F., Chalak, A., \& Biria, R. (2019). Pedagogical Utility of Pre-Listening Activities for Improving Iranian Elementary EFL Learners' Listening Comprehension. International Journal of Instruction, 12(1), 1127-1140. https://doi.org/10.29333/iji.2019.12172a

Li, H. (2018). Application of schema theory to English listening teaching in senior high school. Henan University, Henan, China.

Li, Q. (2014). Schema theory and the teaching of college English news listening. Theory \& Practice in Language Studies, 4(7). https://doi.org/10.4304/tpls.4.7.1469-1475

Richards, J. C., \& Schmidt, R. (2010). Dictionary of language teaching \& applied linguistics. London: Pearson Edition.

Rost, M. (1990). Listening in language learning. Longman.

Rost, M. (2002). Teaching and researching listening. London, UK: Pearson.

Rumelhart, D. E. (1977). Towards an interactive model of reading. Attention and Performance, 6.

Sadighi, F., \& Zare, S. (2002). Is listening comprehension influenced by the background knowledge of the learners? A case study of Iranian EFL learners. The Linguistics Journal, 1(3), 110-126.

Sun, D. M. (2008). Application of schema theory to the teaching of college English listening. Nanjing Normal 
University, Jiangsu, China.

Taylor, S. E., \& Crocker, J. (1981). Schematic bases of social information processing. In E. T. Higgins, C. P. Herman \& M. P. Zanna (Eds.), Social cognition: The Ontario symposium (pp. 89-134). Hillslade, NJ: Lawrence Erlbaum.

Urquhart, A. H., \& Weir, C. (1998). Reading in a Second Language: Process, Product, and Practice. Longman.

Widdowson, H. G. (1983). Learning Purpose and Language Use. Oxford: Oxford University Press.

Wilt, M. E. (1950). A Study of Teacher Awareness of Listening as a Factor in Elementary Education. Journal of Educational Research, 8, 626-636. https://doi.org/10.1080/00220671.1950.10881817

Yang, P., \& Deng, L. H. (2007). Application Limit of Schema Theory in Listening Research. Foreign Languages in China, 4(3), 49-53.

Yang, S. (2010). The influence of schema and cultural difference on L1 and L2 reading. English Language Teaching, 3, 175-180. https://doi.org/10.5539/elt.v3n4p175

Zhang, T. (2013). Limitations of application of schema theory in English listening teaching. Science \& Technology Information, 22, 31-32.

Zhang, X. P., Liu, J., \& Wang, N. (2014). Application of schema theory to English listening teaching in middle school. Overseas English, 24, 108-109.

\section{Copyrights}

Copyright for this article is retained by the author, with first publication rights granted to the journal.

This is an open-access article distributed under the terms and conditions of the Creative Commons Attribution license (http://creativecommons.org/licenses/by/4.0/). 